\title{
ON TEACHING INSTITUTIONS, RESEARCH AND SEPARATE ACCOUNTING ACCREDITATION
}

\author{
Bill Joyce, Department of Accountancy, Bemidji State University, U.S.A.
}

\author{
dx.doi.org/10.18374/JIMS-21-1.1
}

\begin{abstract}
Accreditation is becoming a widely accepted form of program assessment in higher education. The Association to Advance Association to Advance Collegiate Schools of Business (AACSB) is the dominant form or accreditation for both business programs in general and accounting programs specifically. With high research expectations, AACSB accreditation seems to place "teaching" institutions at a disadvantage in gaining accreditation compared to "research" institutions. Forcing "teaching" schools to adopt rigorous research standards may have detrimental consequences to teaching, which is at the very heart of "teaching" institutions. The benefits of AACSB accreditation need to be measured against the high cost of achieving this accreditation. Other means of signaling accounting program credibility may be a viable alternative to separate AACSB accounting program accreditation.
\end{abstract}

Keywords: teaching, research, accreditation 